\title{
Morphometry of bovine blastocysts produced in vitro in culture media with antioxidants cysteamine or oily extract of Lippia origanoides
}

\author{
[Morfometria de blastocistos bovinos produzidos in vitro em meio de cultura com \\ antioxidantes cisteamina ou extrato oleoso de Lippia origanoides] \\ N.V. Sollecito ${ }^{1}$, R.N. Alves ${ }^{2}$, M.E. Beletti ${ }^{2}$, E.C.M. Pereira ${ }^{3}$, M.S. Miranda ${ }^{4}$, \\ J.K.R. Silva ${ }^{4}$, A.M. Borges ${ }^{1}$ \\ ${ }^{1}$ Escola de Veterinária - Universidade Federal de Minas Gerais - Belo Horizonte, MG \\ ${ }^{2}$ Instituto de Ciências Biomédicas - Universidade Federal de Uberlândia - Uberlândia, MG \\ ${ }^{3}$ Faculdade de Medicina Veterinária - Universidade Federal do Mato Grosso - Cuiabá, MT \\ ${ }^{4}$ Faculdade de Biotecnologia - Universidade Federal do Pará - Belém, PA
}

\begin{abstract}
This study aimed to evaluate the ultrastructural morphometry of bovine embryos produced in vitro grown at different concentrations of antioxidants. After in vitro maturation and fertilization, the presumptive zygotes were assigned into five treatments. T1) without the addition of any antioxidants (negative control); T2) addition of $50 \mu \mathrm{M} / \mathrm{mL}$ cysteamine; and T3, T4 and T5) adding $2.5 \mu \mathrm{g} / \mathrm{mL}, 5.0 \mu \mathrm{g} / \mathrm{mL}$ or $10.0 \mu \mathrm{g} / \mathrm{mL}$ of the antioxidants derived from the oily extract from Lippia origanoides, respectively. On D7 of culture, the embryos in the blastocyst stage were fixed and prepared for electron transmission microscopy. These were evaluated for the proportion of cytoplasm-to-nucleus, cytoplasm-to-mitochondria, cytoplasm-to-vacuoles, cytoplasm-to-autophagic vacuoles and cytoplasm-to-lipid droplets. Blastocysts cultured in media containing oily extract of Lippia origanoides presented morphological characteristics such as high cell:mitochondria ratio and low cell:vacuoles and cell:autophagic vacuole ratio, possibly been morphological indicators of embryonic quality. Inner cell mass (ICM) from blastocysts cultured in media without any antioxidants had the highest cell:vacuole ratio. Similar results were found in the trophectoderm (TE) cells of blastocysts from treatment 2. Embryo culture media supplemented with antioxidants derived from Lippia origanoides oil produced embryos with a higher cytoplasmic proportion of organelles, such as mitochondria. Also, treatments without any antioxidants or with the addition of cysteamine presented cytoplasmic vacuolization, a characteristic related to production of poor-quality embryos.
\end{abstract}

Keywords: antioxidants, bovine, in vitro produced embryos, Lippia origanoides, ultrastructural morphometry

\section{RESUMO}

Este estudo teve como objetivo avaliar a morfometria ultraestrutural de embriões bovinos produzidos in vitro e cultivados em diferentes concentrações de antioxidantes. Após a maturação e a fertilização in vitro, os possíveis zigotos foram divididos em cinco tratamentos: T1) sem adição de antioxidantes (controle

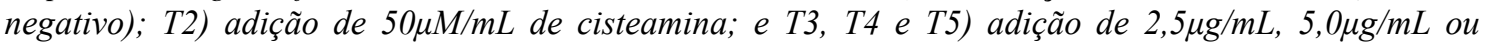
$10,0 \mu \mathrm{g} / \mathrm{mL}$ dos antioxidantes derivados do extrato oleoso de Lippia origanoides, respectivamente. No D7 de cultivo, os embriões em estágio de blastocisto foram fixados e preparados para microscopia eletrônica de transmissão. Estes foram avaliados para a proporção entre citoplasma e núcleo, citoplasma e mitocôndria, citoplasma e vacúolos, citoplasma e vacúolos autofágicos e citoplasma e gotículas lipídicas. Blastocistos cultivados em meio contendo extrato oleoso de Lippia origanoides apresentaram características morfológicas como alta relação célula:mitocôndria e baixa relação célula:vacúolos e célula:vacúolo autofágico, possivveis indicadores morfológicos de qualidade embrionária. A massa celular interna (MCI) de blastocistos cultivados em meio sem quaisquer antioxidantes teve a maior razão célula:vacúolo. Resultados semelhantes foram encontrados nas células do trofectoderma (TE) de

Recebido em 26 de outubro de 2020

Aceito em 11 de março de 2021

E-mail: nat.sol86@yahoo.com.br 
blastocistos do tratamento 2. Portanto, o meio de cultivo embrionário suplementado com antioxidantes derivados do óleo de Lippia origanoides produziu embriões com maior proporção citoplasmática de organelas, como mitocôndrias. Além disso, tratamentos sem antioxidantes ou com adição de cisteamina apresentaram vacuolização citoplasmática, característica relacionada à produção de embriões de baixa qualidade.

Palavras-chave: antioxidantes, bovinos, embriões produzidos in vitro, Lippia origanoides, morfometria ultraestrutural

\section{INTRODUCTION}

In vitro embryo production (IVEP) is a wellknown and widespread biotechnology in human and animal reproduction. However, embryo culture conditions still lead to limitations associated to poor-quality embryos (Pereira $\mathrm{et} \mathrm{al.,}$ 2005; Rizos et al., 2008), evaluated by morphologic, metabolic characteristics as well by gene expression. Once oocyte maturation and fertilization process occur outside the body environment (in vivo), the in vitro conditions expose gametes and embryos to external factors that potentiate the production of reactive oxygen species (ROS), that is a natural process occurring in embryos and all cellular types. The results of mitochondrial phosphorylated oxidation, ROS participate in intracellular redox regulation and several cell signaling pathways, crucial to embryonic development (Ufer et al., 2010; Timme-Laragy et al., 2013). However, when in excess, ROS reduces the efficiency of IVEP (Crocomo et al., 2012).

Normally, embryonic culture occurs under conditions where antioxidant supplementation is in lower concentration than the necessary required to control ROS production, trigging oxidative stress to different cell types (Elamaran et al., 2012). The addition antioxidant supplementation in culture media has been the alternative way to mitigate cell damage caused by the oxidative stress in in vitro embryo production systems. The oily extract of the Lippia origanoides, a native plant from South America, had been initially used due to therapeutical properties (Pascual et al., 2001), and as an alternative antioxidant to be added to maturation of oocytes (Pereira, 2015) and in vitro culture media (Sollecito et al., 2019) of bovine embryos, since a study with buffalo showed greater number of blastocysts cells after oocytes been cultivated in maturation media added with oily extract of Lippia origanoides (Pereira, 2015). Since Lippia origanoides oil is rich in compounds such as carvacrol and thymol, the supplementation in culture media provides an increase in intracellular glutathione concentrations (Teixeira et al., 2014; Sarrazin et al., 2015). The aim of this study was to evaluate the ultrastructural morphology of bovine blastocysts produced in vitro in media supplemented with different antioxidants.

\section{MATERIAL AND METHODS}

The experiment was carried out in accordance with the standards of the Ethics Committee for the Use of Animals (CEUA/UFMG), under protocol number 339/2016. All reagents and media used in the experiment were from Sigma-Aldrich ( $\mathrm{St}$ Louis, MO, USA). The ovaries were collected from a slaughterhouse and kept at $38^{\circ} \mathrm{C}$ in $0.9 \%$ $\mathrm{NaCl}$ saline solution until the time of follicular aspiration. Follicles with a diameter of $2-8 \mathrm{~mm}$ were aspirated and the follicular fluid was placed in a $50 \mathrm{~mL}$ Falcon tube until selection of the cumulus-oocyte complexes (COCs). The selection of COCs was performed in TCM-199 HEPES medium, supplemented with $22 \mu \mathrm{g} / \mathrm{mL}$ of sodium pyruvate, $50 \mu \mathrm{g} / \mathrm{mL}$ of amikacin sulfate and $10 \%$ of fetal bovine serum (FBS). Oocytes were selected with compact cumulus, with two or more layers of cells and homogeneous and integral cytoplasm (Seneda et al., 2001), using a stereomicroscope.

The COCs were matured for 22 to 24 hours at $38.5^{\circ} \mathrm{C}$ under atmosphere of $5 \% \mathrm{CO}_{2}$ and $95 \%$ air with high humidity (Thermo Scientific, USA). In vitro maturation was performed in TCM-199 bicarbonate medium supplemented with $10 \%$ FBS, $22 \mu \mathrm{g} / \mathrm{mL}$ sodium pyruvate, $50 \mu \mathrm{g} / \mathrm{mL}$ amikacin sulfate, $5 \mu \mathrm{g} / \mathrm{mL}$ LH (Lutropin- $\mathrm{V}^{\circledR}$, Bioniche Inc., Canada), $1 \mu \mathrm{g} / \mathrm{mL}$ FSH (Folltropin$\mathrm{V}^{\circledR}$, Bioniche Inc, Canada), $10 \mu \mathrm{g} / \mathrm{mL}$ of estradiol and $2.5 \mu \mathrm{g} / \mathrm{mL}$ of Lippia origanoides oily extract. Groups of 15 oocytes were matured in $70 \mu \mathrm{L}$ drops of maturation medium, covered with mineral oil. 
After maturation, the oocytes were inseminated using conventional Holstein bull frozen semen with proven in vitro fertilization (IVF) fertility. Semen was thawed in a water bath at $37^{\circ} \mathrm{C}$ for $30 \mathrm{~s}$ and spermatozoa were prepared using a $90-45 \%$ discontinuous percoll density gradient (Parrish et al., 1984). After the first centrifugation $(1700 x G)$ the spermatozoa were resuspended in TALP medium and centrifuged again $(420 \mathrm{xG})$. The pellet formed from mobile spermatozoa was diluted in IVF medium and added in drops of $70 \mu \mathrm{L}$ of IVF medium at the inseminating dose of 14,000 spermatozoa/drop in a drop of $100 \mu \mathrm{L}$ of Fert-Talp medium supplemented with amikacin $(83.4 \mu \mathrm{g} / \mathrm{mL}), \quad$ penicillamine $(2.7 \mu \mathrm{g} / \mathrm{mL})$, hypotaurine $(1 \mu \mathrm{g} / \mathrm{mL})$, epinephrine $(0.3 \mu \mathrm{g} / \mathrm{mL})$, bovine serum albumin $(5 \mu \mathrm{g} / \mathrm{mL})$, pyruvate $(22 \mu \mathrm{g} / \mathrm{mL})$, and heparin $(10 \mu \mathrm{g} / \mathrm{mL})$. The gametes were co-incubated at $38.5^{\circ} \mathrm{C}$ under atmosphere of $5 \% \mathrm{CO}_{2}$ and air with high humidity for 20 hours.

After fertilization (day zero, D0 = IVF day), the presumptive zygotes were submitted to successive pipetting for the mechanical removal of the cumulus-oophurus cells. The zygotes were cultured in vitro in drops of cultured medium (Modified Synthetic Oviduct Fluid - SOF- $m$ ) supplemented with $2.5 \%$ FBS covered with mineral oil, in an incubator at $38.5^{\circ} \mathrm{C}$ under atmosphere of $5 \% \mathrm{CO}_{2}, 5 \% \mathrm{O}_{2}$ and air with high humidity. About 15 zygotes per drop were assigned according to the respective treatment, according to concentration used by Sollecito et al. (2019): T1- embryonic culture medium without any antioxidant; T2- embryo culture medium with addition of $50 \mu \mathrm{M} / \mathrm{mL}$ of the antioxidant cysteamine; and T3, T4 and T5 - embryo culture medium with addition of $2.5 \mu \mathrm{g} / \mathrm{mL}, 5.0 \mu \mathrm{g} / \mathrm{mL}$ and $10.0 \mu \mathrm{g} / \mathrm{mL}$ of the antioxidant derived from the oily extract of Lippia origanoides, respectively. Oily extract from Lippia origanoides $(0.002 \mathrm{~g})$ was diluted in $200 \mu \mathrm{L}$ of DMSO to form the stock solution. Next, $10 \mu \mathrm{L}$ of the stock solution was further diluted in $1990 \mu \mathrm{L}$ of TCM-199 HEPES medium, for the addition of the oil to the embryo culture media. On the seventh day of culture (D7), the embryos at the blastocyst stage (Bl) were prepared for analysis in transmission electron microscopy.
For electron microscopy, 30 blastocysts (B1) from each treatment were fixed in $2.5 \%$ glutaraldehyde and $0.1 \mathrm{M}$ phosphate buffer, washed three times in PBS + FBS (3\%) solution, and the embryos were deposited in $600 \mu \mathrm{l}$ eppendorf tubes, and subsequently $1 \%$ osmium tetroxide was added, and the mixture remained for 1 hour. Supernatant was removed, and the embryos present in the pellet were immersed in 3\% agar. After agar gelatinization, they were packed in glass jars. After undergoing dehydration in increasing alcohol concentrations, the samples of the different treatments were immersed overnight in propylene oxide and 2:1 resin. The next day, the material was soaked with a new 1:1 solution of propylene oxide and resin. After 12 hours, the samples were kept overnight in an oven at $37^{\circ} \mathrm{C}$ and the next day the solutions were discarded and pure resin was added to the vials, which remained for 4 hours in an oven at $37^{\circ} \mathrm{C}$. The material was placed in inclusion forms in the oven at $60^{\circ} \mathrm{C}$ for two days. Ultra-thin cuts were performed with the Reichert-Jung Ultramicrotome, which were contrasted with uranyl acetate and lead citrate and then observed on the Hitachi HT7700 transmission electron microscope.

Morphometric analysis was performed using a total of 100 electronic micrographs for the blastocysts of each treatment. For the determination of total areas from cytoplasm and organelles, the point-to-point counting method of the Image-J program was used (Schneider et al., 2012), discarding the intercellular area. The proportion of the total cell area in relation to the nucleus, mitochondria, vacuoles, autophagic vacuoles, and lipid droplets was evaluated. Electron microscopy was done in two different groups of cells from the blastocysts, trophectoderm (TE) and inner cell mass (ICM). An example of micrographs is showed in Figure 1. The areas of blastocyst cells were analyzed (Figure 1A and 1B). In addition, the proportions found in two cell types, trophectoderm (TE) (Figure1C) and inner cell mass (ICM) (Figure1D) were also evaluated. 

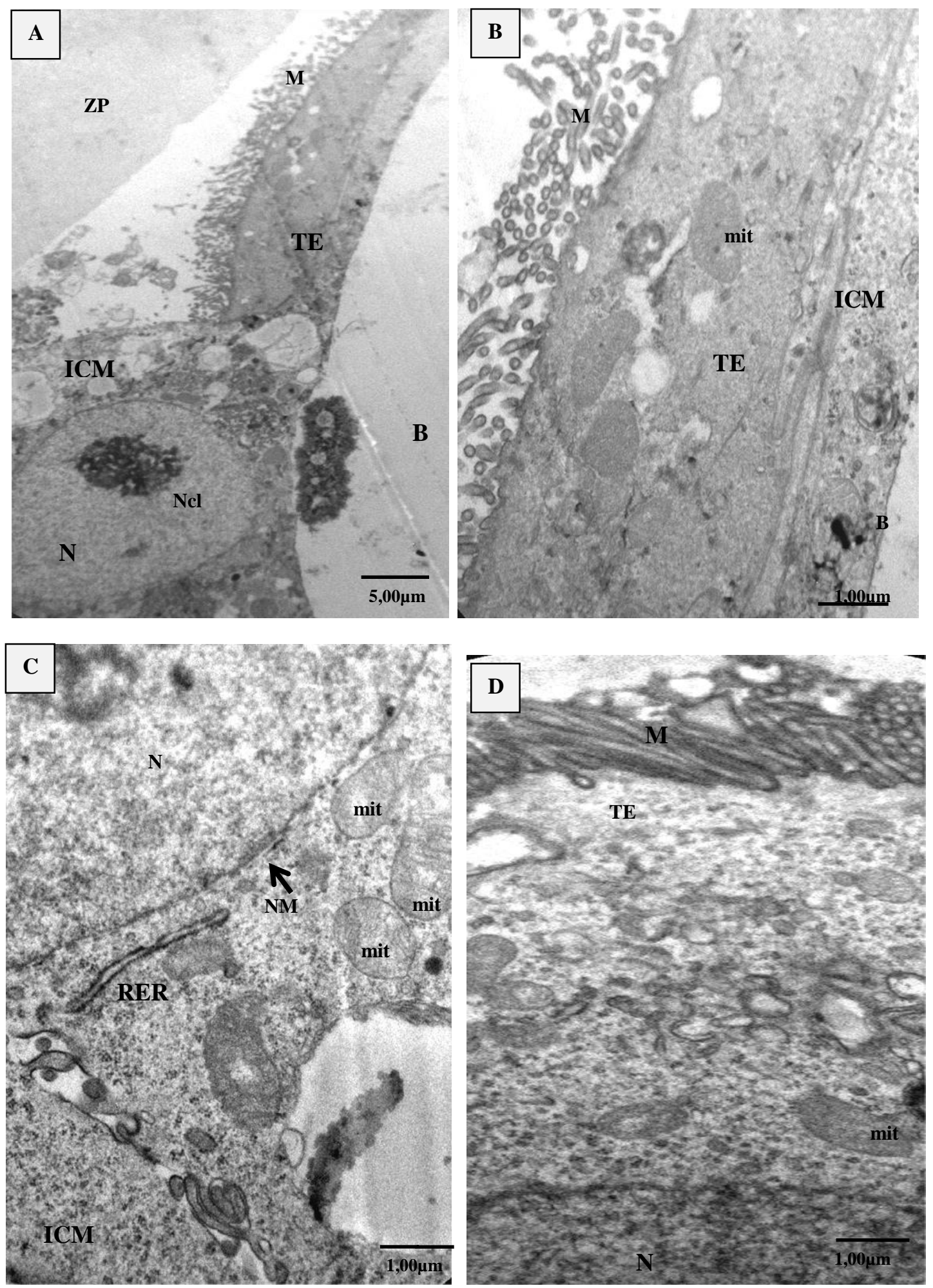

Figure 1. Crossbred bovine blastocysts. Representative electron microscopy sections of cells from the inner cell mass (ICM) (A and C) and cells of the trophectoderm (TE) (B and D) of bovine embryos produced in vitro. In detail, the zona pellucida (ZP), nucleus $(\mathrm{N})$, nucleolus $(\mathrm{Ncl})$, microvilli $(\mathrm{M})$ on the cell surface, blastocele cavity $(\mathrm{B})$, nuclear membrane (NM; black arrow), mitochondria (mit) and the rough endoplasmic reticulum (RER). 
The proportion data between the cytoplasmic area and the other organelles were analyzed by ANOVA test, when they obeyed the standard of normality. When the data were not normally distributed, the Kruskall-Wallis non-parametric test was used to verify possible statistically significant variations among the treatments. The level of significance was $95 \%$ ( $\mathrm{P}<0.05)$. Data were evaluated using SPSS software version 17.0 (SPSS Inc, Chicago, USA).

\section{RESULTS AND DISCUSSION}

The proportion of total area $(\mu \mathrm{m})$ of blastocyst cytoplasm-to-nucleus (Cel:Nuc), to-mitochondria (Cel:Mit), to-vacuoles (Cel:V), to-autophagic vacuoles (Cel:VA) and to-lipids (Cel:Lip) areas are shown in the Table 1. Based on these results, the specific proportions from different areas in the inner cell mass (Table 2) and trophectoderm (Table 3) of blastocysts were measured in relation to the area of organelles.

Table 1. Proportion (\%) of the total area $(\mu \mathrm{m})$ of crossbred bovine blastocyst cells $(\mathrm{Cel})$ on the seventh day of culture (D7) in relation to the nucleus (Nuc), mitochondria (Mit), vacuoles (V), autophagic vacuoles (VA) and lipid droplets (Lip) areas. Data are expressed as means \pm standard error of the mean

\begin{tabular}{|c|c|c|c|c|c|}
\hline $\begin{array}{l}\text { Proportion (\%) } \\
\text { Group }\end{array}$ & Cel:Nuc & Cel:Mit & Cel:V & Cel:VA & Cel:Lip \\
\hline T1- without antioxidants & $31.7 \pm 5.5 \mathrm{a}$ & $9.2 \pm 0.6 \mathrm{a}$ & $17.1 \pm 1.7 \mathrm{a}$ & $2.2 \pm 0.6 \mathrm{a}$ & $3.1 \pm 0.9 \mathrm{a}$ \\
\hline T2- 50 $\mu$ L Cysteamine & $26.3 \pm 4.9 a$ & $7.4 \pm 0.4 \mathrm{ab}$ & $17.0 \pm 1.0 \mathrm{a}$ & $5.7 \pm 1.8 b$ & $2.2 \pm 0.4 \mathrm{a}$ \\
\hline $\mathrm{T} 3-2.5 \mu \mathrm{g}$ Lippia origanoides & $39.6 \pm 4.2 \mathrm{a}$ & $10.2 \pm 0.5 \mathrm{ac}$ & $10.5 \pm 1.1 \mathrm{~b}$ & $9.2 \pm 2.1 \mathrm{~b}$ & $2.3 \pm 0.3 \mathrm{a}$ \\
\hline T4- 5.0ug Lippia origanoides & $37.6 \pm 4.0 \mathrm{a}$ & $8.2 \pm 0.7 \mathrm{ab}$ & $12.8 \pm 1.7 \mathrm{~b}$ & $6.6 \pm 1.6 b$ & $1.2 \pm 0.1 \mathrm{a}$ \\
\hline T5-10.0ug Lippia origanoides & $33.8 \pm 3.3 \mathrm{a}$ & $6.8 \pm 0.4 b$ & $9.6 \pm 0.9 b$ & $6.8 \pm 1.2 b$ & $2.4 \pm 0.3 a$ \\
\hline
\end{tabular}

Table 2. Proportion (\%) between the total area $(\mu \mathrm{m})$ of cells (Cel) of the Inner Cell Mass (ICM) in relation to the nucleus (Nuc), mitochondria (Mit), vacuoles (V) and autophagic vacuoles (VA) in crossbred bovine blastocysts. Data are expressed as means \pm standard error of the mean

\begin{tabular}{|c|c|c|c|c|}
\hline $\begin{array}{c}\text { Proportion (\%) ICM } \\
\text { Group }\end{array}$ & Cel:Nuc & Cel:Mit & Cel:V & Cel:VA \\
\hline T1- without antioxidants & $28.8 \pm 5.8 \mathrm{a}$ & $7.3 \pm 1.7 \mathrm{a}$ & $18.6 \pm 3.9 a$ & $1.4 \pm 0.5 \mathrm{a}$ \\
\hline T2- 50 $\mu$ L Cysteamine & $41.1 \pm 6.7 \mathrm{a}$ & $6.0 \pm 0.7 a$ & $16.0 \pm 2.2 \mathrm{ab}$ & $4.6 \pm 1.3 \mathrm{a}$ \\
\hline T3- $2.5 \mu \mathrm{g}$ Lippia origanoides & $41.6 \pm 6.8 \mathrm{a}$ & $9.7 \pm 1.2 \mathrm{a}$ & $10.1 \pm 1.8 \mathrm{ab}$ & $15.1 \pm 10.2 \mathrm{a}$ \\
\hline T4- 5.0ug Lippia origanoides & $43.7 \pm 6.4 a$ & $5.7 \pm 1.4 \mathrm{a}$ & $6.3 \pm 2.8 \mathrm{~b}$ & $4.9 \pm 0.2 \mathrm{a}$ \\
\hline 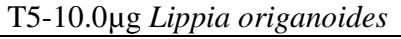 & $44.6 \pm 9.2 \mathrm{a}$ & $8.1 \pm 1.1 \mathrm{a}$ & $9.8 \pm 3.1 \mathrm{ab}$ & $4.3 \pm 1.4 \mathrm{a}$ \\
\hline
\end{tabular}

${ }^{\mathrm{abc}}$ Averages with different letters in the same column differ from each other $(\mathrm{P}<0.05)$ by the Kruskall-Wallis test.

Table 3. Proportion (\%) of total area $(\mu \mathrm{m})$ of Trophectoderm (TE) cells relative to nucleus (Nuc), mitochondria (Mit), vacuoles (V), autophagic vacuoles (VA) and droplets lipids (Lip) in crossbred bovine blastocysts. Data are expressed as means \pm standard error of the mean

\begin{tabular}{|c|c|c|c|c|c|}
\hline $\begin{array}{c}\text { Proportion (\%) TE } \\
\text { Group }\end{array}$ & Cel:Nuc & Cel:Mit & Cel:V & Cel:VA & Cel:Lip \\
\hline T1- without antioxidants & $33.6 \pm 8.5 \mathrm{ab}$ & $9.6 \pm 0.6 \mathrm{ab}$ & $16.8 \pm 1.8 \mathrm{ab}$ & $2.4 \pm 0.7 \mathrm{a}$ & $3.2 \pm 1.1 \mathrm{a}$ \\
\hline T2- 50 $\mu$ L Cysteamine & $17.7 \pm 5.6 \mathrm{a}$ & $7.7 \pm 0.5 b$ & $17.2 \pm 1.1 \mathrm{a}$ & $6.4 \pm 2.8 \mathrm{a}$ & $2.2 \pm 0.4 \mathrm{a}$ \\
\hline 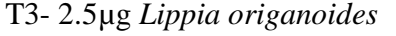 & $37.9 \pm 5.5 b$ & $10.4 \pm 0.6 \mathrm{a}$ & $10.6 \pm 1.4 \mathrm{bc}$ & $8.5 \pm 2.1 \mathrm{a}$ & $2.1 \pm 0.4 \mathrm{a}$ \\
\hline 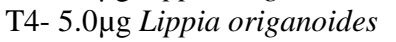 & $33.7 \pm 5.0 \mathrm{~b}$ & $8.8 \pm 0.8 b$ & $14.9 \pm 2.0 \mathrm{abc}$ & $7.0 \pm 2.0 \mathrm{a}$ & $1.4 \pm 0.2 \mathrm{a}$ \\
\hline 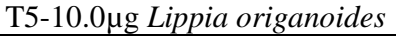 & $31.0 \pm 3.4 \mathrm{~b}$ & $6.4 \pm 0.4 \mathrm{c}$ & $9.5 \pm 0.9 \mathrm{c}$ & $7.5 \pm 1.5 \mathrm{a}$ & $1.0 \pm 0.2 \mathrm{a}$ \\
\hline
\end{tabular}

${ }^{a b c}$ Averages with different letters in the same column differ from each other $(\mathrm{P}<0.05)$ by the Kruskall-Wallis test.

The use of antioxidants in in vitro embryos production systems has shown promising results improving embryo quality, increasing cryotolerance and reducing the apoptosis rate in embryo cells, as well as increasing postimplantation development and successful embryo transfer (Sun et al., 2015, Rocha-Frigoni et al., 2016; Zullo et al., 2016a, b). Based on the morphometric analysis in the present study, supplementation of the embryonic culture medium with antioxidants can induce alterations in the ultrastructural morphology of intracellular organelles of bovine blastocysts produced in vitro that indirectly is related to the quality of the embryos. The cell:nucleus area ratio did not differ (P>0.05) among treatments when analyzed grouping different cell types of blastocysts and in ICM cells. For the trophectoderm (TE) cells, there 
were differences $(\mathrm{P}<0.05)$ between $\mathrm{T} 2$ in comparison to the treatments with the addition of oily extract of Lippia origanoides in the culture.

Higher proportion of cell:nucleus can be verified in treatments T3, T4 and T5 when compared to $\mathrm{T} 2$. There was no difference $(\mathrm{P}>0.05)$ between $\mathrm{T} 2$ and control group. Also, treatment 1 did not differ $(\mathrm{P}>0.05)$ from treatments including Lippia origanoides in the culture medium. Possible the lower proportion of the cell:nucleus area in the trophectoderm cells from treatment 2 is related to the low rate of cell division, reducing differentiation and the number of cells in cysteamine treatment (Crosier et al., 2001). The proportion between cell:mitochondria area from different cell types of blastocysts and trophectoderm cells was higher $(\mathrm{P}<0.05)$ for $\mathrm{T} 3$ embryos, which presented the highest proportion of mitochondria per area, while T5 presented the lowest proportion $(\mathrm{P}<0.05)$. There was no difference $(\mathrm{P}>0.05)$ in this proportion between the different treatments in the ICM cells. Mitochondria are extremely important for full embryonic development, since they are the organelles responsible for generating energy, by supplying ATP for other cellular activities (Wilding et al., 2009; Chappel, 2013). In addition, besides to the quantitative number of mitochondria in the cell, it is essential to evaluate the normal conformation and the well-developed cristae distributed throughout the mitochondrial matrix (Cheville, 2009).

Although treatment 5 (Figure 2C) presented a smaller proportion between total cytoplasmic area and the area of its mitochondria, in this treatment the mitochondria had very evident and numerous cristae. Instead, treatments 1 and 3 had sparsecristae mitochondria with intramitochondrial vacuoles, although they had a larger area ratio (Figure 2A and 2B). According to Bavister and Squirrel (2000), the mitochondria found in oocytes and embryos at the beginning of development are structurally immature, with rounded or oval conformation, exhibiting few cristae and presence of vacuoles, elongating, and increasing the number of mitochondrial cristae after the first cleavages of the embryo. Therefore, the proportion of cellular area occupied by mitochondria and its morphology, which has a positive correlation to cell quality, should be evaluated together.
The present study was performed with embryos at the blastocyst stage after the maternal-zygotic transition. Thus, it is common to find an increasing in the mitochondria and cristae number on inner membrane. Treatment 3 presented a high proportion of cell:mitochondria but a lower number of mitochondrial cristae. The increase in the number of mitochondria is correlated to fragmentation of these organelles and the increase in the number of apoptotic bodies, as demonstrated by Karbowski and Youle (2003) in a study that indicated elevation of apoptotic fragments in the TUNEL (Terminal deoxynucleotidyl transferase dUTP nick end labeling) assay. A similar result was found by our research group (Sollecito et al., 2019 that used the same concentrations $(2.5,5.0$ and $10.0 \mu \mathrm{g} / \mathrm{mL})$ of oil extracted from Lippia origanoides in the in vitro embryo culture media. Treatments without any antioxidant or supplement with $2.5 \mu \mathrm{g} / \mathrm{mL}$ of oil extract from Lippia origanoides showed higher apoptotic index. Similarly, when correlated with the present study, treatments with 5.0 and $10.0 \mu \mathrm{g} / \mathrm{mL}$ of Lippia origanoides presented the highest proportions $(\mathrm{P}<0.05)$ of mitochondria per cytoplasmic area.

Regarding the proportion of the cell:vacuoles area in blastocyst cells, treatments 1 and 2 presented the highest $(\mathrm{P}<0.05)$ amount of vacuoles distributed in the cytoplasm (Figure $3 \mathrm{~A}$ and $3 \mathrm{~B}$ ) and showed spherical and with a light gray or translucent color, in comparison to the other treatments supplemented with the oil extract of Lippia origanoides (Figure 3C). In other treatments, it was also possible to observe this type of vesicles, but to a lesser extent. This characteristic of a high proportion of vacuoles by cytoplasmic area was also observed in ICM and TE cells from treatment $2(\mathrm{P}<0.05)$. Although the ICM cells presented areas of vacuolization, the largest area was found in the TE cells. The lowest proportion was verified in $\mathrm{T} 4$ for inner cell mass and in $\mathrm{T} 5$ for trophectoderm $(\mathrm{P}<0.05)$. These findings are consistent with the majority of studies that evaluated embryonic morphology and found greater vacuolization in trophectoderm (TE) cells (Ebner et al., 2005; Hardarson et al., 2012), which can be explained as an embryonic strategy to minimize exacerbated ICM vacuolation at implantation (Ebner et al., 2011). 

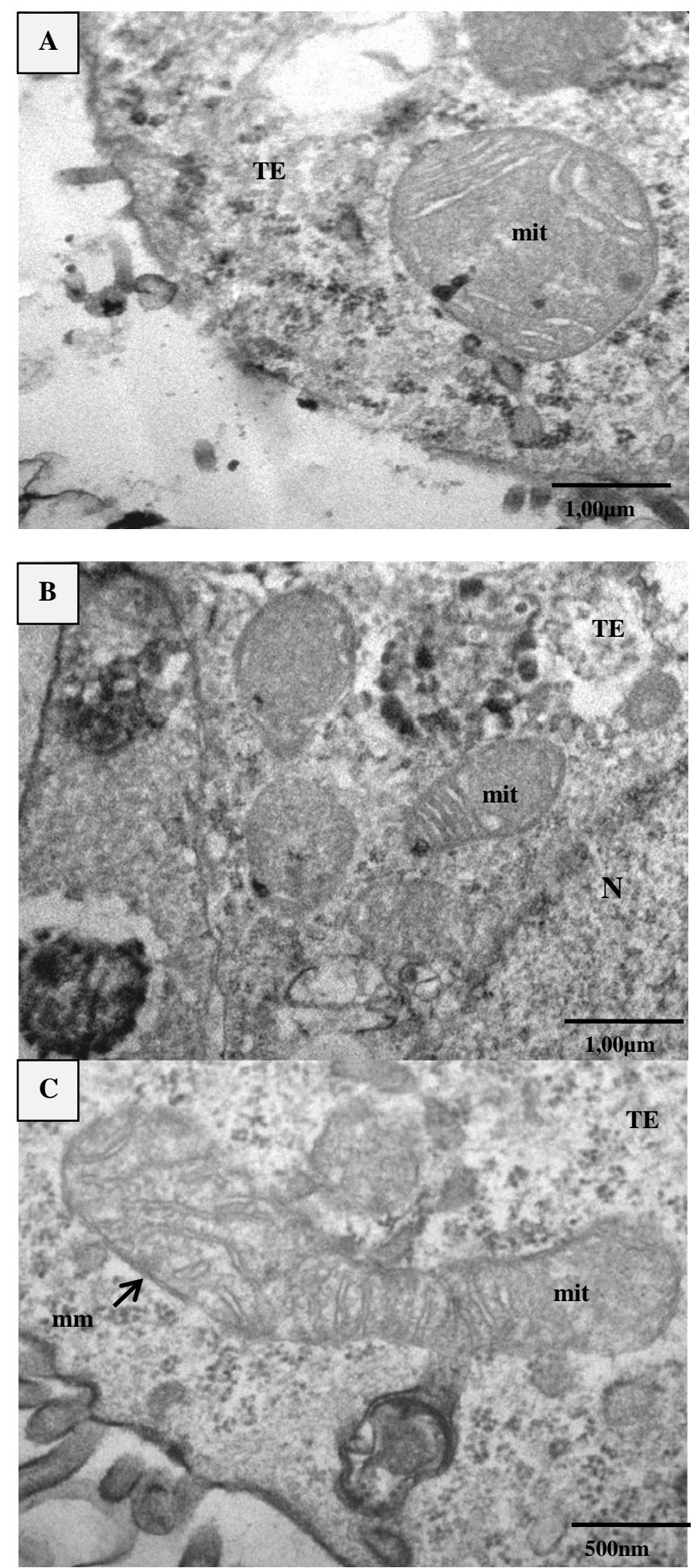

Figure 2. Crossbred bovine blastocysts. Electromicrography of the types of mitochondria (mit) found in the trophectoderm (TE) cells of bovine blastocysts produced in vitro in different culture media. A) Mitochondria (mit) from treatment 1 (without any addition of antioxidants) with the central region without ridges; B) Mitochondria from treatment 3 (addition of $2.5 \mu \mathrm{g} / \mathrm{mL}$ Lippia origanoides) containing few crests; and C) Mitochondria belonging to treatment 5 (addition of $10.0 \mu \mathrm{g} / \mathrm{mL}$ Lippia origanoides) elongated with mitochondrial membrane (mm; black arrow) well evidenced and numerous crests. 


\section{Sollecito et al.}
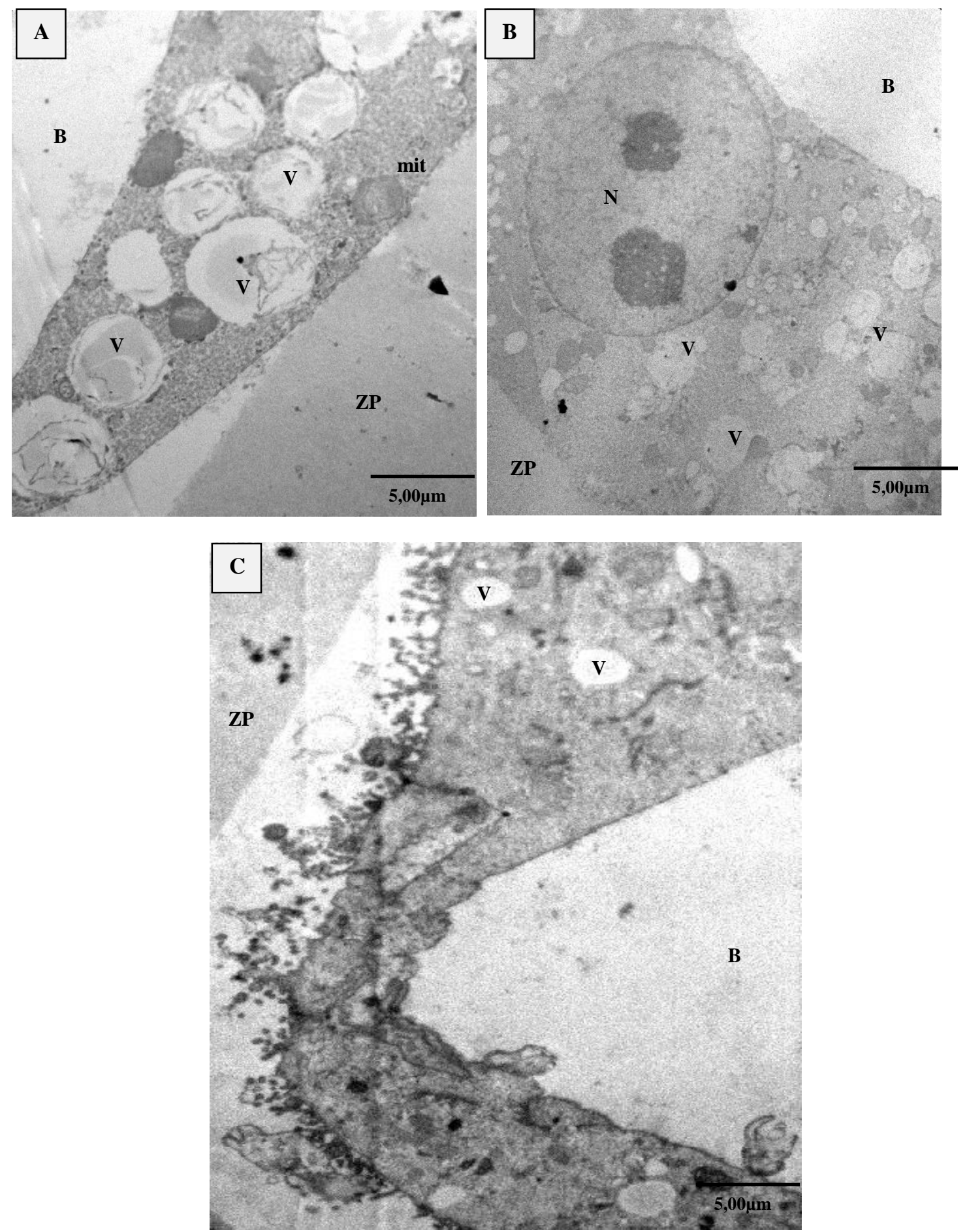

Figure 3. Crossbred bovine blastocysts. Electromicrography of trophectoderm (TE) cells from bovine embryos produced in vitro. A) Vacuoles of different sizes are observed inside blastocysts cultured without any antioxidant supplementation (treatment 1); B) Vacuoles present in blastocysts grown in medium supplemented with $50 \mu \mathrm{M} / \mathrm{mL}$ of the antioxidant cysteamine (treatment 2); C) Small vacuoles present in the blastocysts cultured with $10.0 \mu \mathrm{g} / \mathrm{mL}$ of the oil extracted from Lippia origanoides (treatment 5). Details of the nucleus (N), zona pellucida (ZP), blastocele (B), vacuoles (V) and mitochondria (mit) can be observed. 
Vacuoles are cytoplasmic inclusions attached to the membrane, filled with fluid similar to that found in the perivitelline fluid, and their number and size range significantly among cells. The increasing in size of the vacuoles may occurs spontaneously or by fusion between pre-existing vesicles derived from the smooth endoplasmic reticulum and/or the Golgi complex. However, even if it is a natural event, increasing vacuolation in gametes and embryonic cells is strongly associated with failure in in vitro embryo production (Van Blerkon, 1990). Similar results were observed in human embryos derived from ICSI and IVEP, in which the vacuolization had a negative impact on the blastocyst formation (Ebner et al., 2005).

Evaluation of autophagic vacuoles showed there was lower $(\mathrm{P}<0.05)$ cell:autophagic vacuoles ratio in blastocysts from treatment 1 compared to other treatments. In the ICM and TE cells, few vacuoles of this category were found $(\mathrm{P}>0.05)$. Vacuoles can progress to the formation of autophagic vacuoles (or autolysosomes) which are responsible for performing the normal mechanism of elimination of old and inefficient organelles. However, when there is an increase in these vacuoles, it means that there is sublethal intracellular focal injury caused by noxious agent (Cheville, 2009). Recent studies have shown that autophagy is responsible for decreasing the damage caused by excessive ROS production and maintain cellular homeostasis (Shin et al., 2014).

In the present study, the difference between the appearance of the vacuoles was evident, as can be seen in Figure 4. Although treatment 1 had a smaller number of autophagic vacuoles $(\mathrm{P}<0.05)$, more translucent vacuoles are observed, or the presence of lighter amorphous substance within it. In the other treatments, presenting more vacuoles of the autophagic type, the aspects were variable but most presented darker coloration, with poorly defined limits. This can be explained by the fact that it is a vacuole that performs the digestion of other organelles and may be in several stages of degradation until it reaches the production of a residual body that contains undigested electrondense lipid residues (Cheville, 2009).
The morphological relationship between mitochondria and autophagic vacuoles was also verified in the present study. It was possible to observe that autophagy often started from mitochondrial degeneration, demonstrated by the proximity of vacuoles with mitochondria that apparently were losing their shape (apoptotic) (Figure 5). This association may be justified by the attempt to eliminate possibly defective mitochondria (Mortensen et al., 2010), in order to allow the embryo to proceed with its development. The proportion of the cell:lipid area in the blastocyst cells, ICM and TE did not differ ( $P>0.05)$ between treatments. When analyzing the lipid droplets present in embryonic cells, the proportion in relation to the total cell area was low in all treatments and did not differ $(\mathrm{P}>0.05)$ (Figure 6).

This finding differs from what was found by Crosier et al. (2001), who performed a morphometric study to verify the presence of large volumes of lipid droplets in bovine embryos produced in vitro. This result was explained by the addition of fetal bovine serum (10\%) to the culture medium. Although the present study also added FBS to culture medium, it was in a lower concentration $(2.5 \%)$ which could justify the low lipid ratio in the cytoplasm of the embryonic cells. The lipid droplets are negatively correlated to embryonic freezability and vitrification process, which impairs the success of embryo transfer (Pereira and Marques, 2008).

Recent studies have shown that bovine embryos produced in vitro in media with the addition of several types of antioxidants have become more cryotolerant (Zullo et al., 2016b; Salzano et al., 2014). In the present study, results did not find a significant ratio $(\mathrm{P}>0.05)$ between cell:lipid droplet area, indicating that other trials need to be done to test the correlation of morphological aspects of embryos produced in media supplemented with antioxidants (T2, T3, T4 and $\mathrm{T} 5$ ), the reduction of lipid content in the cytoplasm of embryos and their quality and resistance to cryopreservation as found by previous studies (Zullo et al., 2016b; Salzano et al., 2014). 


\section{Sollecito et al.}
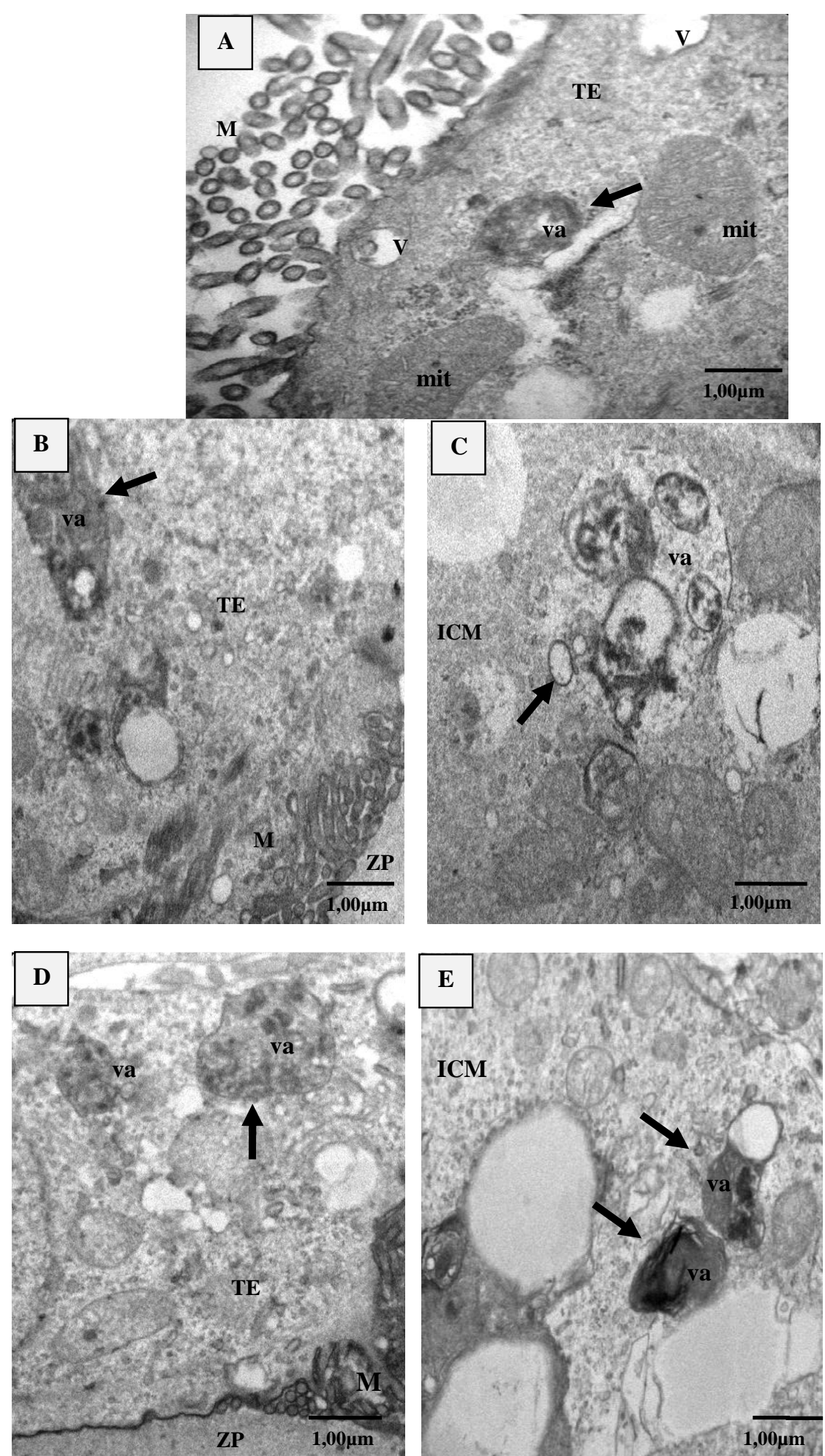

Figure 4. Crossbred bovine blastocysts. Electromicrography of trophectoderm (TE) and inner cell mass (ICM) from bovine embryos produced in vitro containing autophagocytic (va) vacuoles at several stages. A) Treatment 1 , B) Treatment 2, C) Treatment 3, D) Treatment 4 and E) Treatment 5. The autophagic vacuoles are indicated by the arrows. 


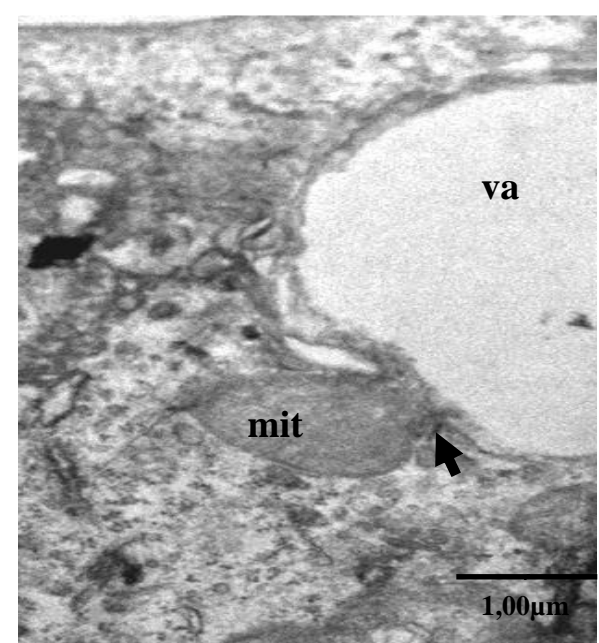

Figure 5. Crossbred bovine blastocyst. Electromicrography of cell from a bovine in vitro produced embryo showing mitochondrial degeneration (mit) by means of the process of autophagy. The black arrow indicates where the formation of the autophagic vacuole (va) is occurring.

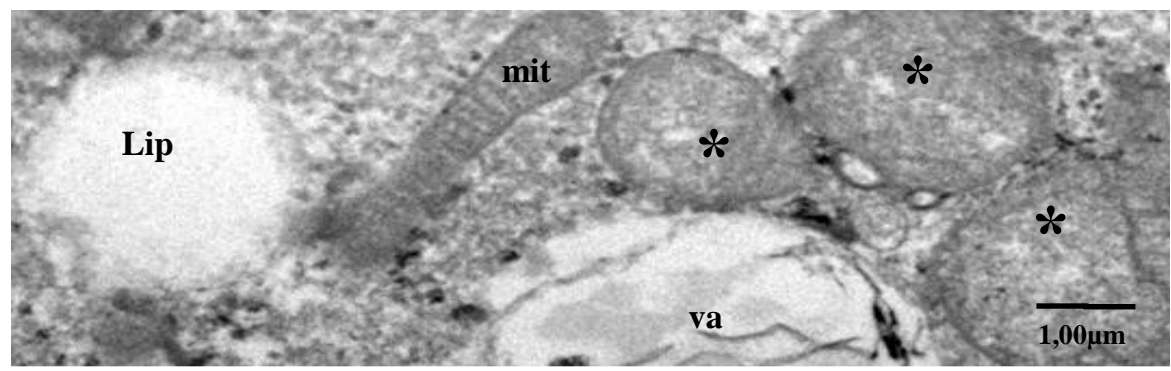

Figure 6. Crossbred bovine blastocyst. Electromicrography of trophectoderm (TE) cell from treatment 2 showing lipid droplet (Lip), autophagic vacuole (va), mitochondria (mit) and mitochondria in an advanced stage of degeneration (asterisks).

\section{CONCLUSION}

In conclusion, in vitro culture in media supplemented with the oily extract of Lippia origanoides resulted in bovine embryos with lower proportion areas of vacuoles and higher proportion of mitochondrial area, and large amounts of ridges on inner membrane, suggesting a better-quality embryo.

\section{ACKNOWLEDGMENTS}

The authors thank Coordenação de Aperfeiçoamento de Pessoal de Nível Superior (CAPES), Fundação de Amparo à Pesquisa do Estado de Minas Gerais (FAPEMIG), Conselho Nacional de Desenvolvimento Científico e Tecnológico (CNPq), and all collaborators for their guidance and financial support.

\section{REFERENCES}

BAVISTER, B.D.; SQUIRRELL, J.M. Mitochondrial distribution and function in oocytes and early embryos. Hum. Reprod., v.15, p.189-198, 2000.

CHAPPEL, S. The role of mitochondria from mature oocyte to viable blastocyst. Obstet. Gynecol. Int., v.2013, p.10, 2013.

CHEVILLE, N.F. Ultrastructural pathology: the comparative cellular basis of disease. 2.ed. Iowa, USA: Wiley-Blackwell, 2009. 1000p.

CROCOMO, L.F.; MARQUES FILHO, W.C.; LANDIM-ALVARENGA, F.C. et al. Produção de embriões in vitro: estresse oxidativo e antioxidantes. Vet. Zootec., v.19, p.470-479, 2012. 
CROSIER, A.E.; FARIN, P.W.; DYKSTRA, M.J. et al. Ultrastructural morphometry of bovine blastocysts produced in vivo or in vitro. Biol. Reprod., v.64, p.1375-1385, 2001.

EBNER, T.; MOSER, M.; SOMMERGRUBER, $M$. Occurrence and developmental consequences of vacuoles throughout preimplantation development. Fertil. Steril., v.83, p.1635-1640, 2005.

EBNER, T.; VANDERZWALMEN, P.; SHEBL, O. et al. Morphological Aspects of human blastocysts and the impact of vitrification. $J$. Reproduktionsmed. Endokrinol., v.8, p.13-20, 2011.

ELAMARAN, G.; SINGH, K.P.; SINGH, M. K. et al. Oxygen concentration and cysteamine supplementation during in vitro production of Buff alo (Bubalus bubalis) embryos aff ect mRNA expression of BCL-2, BCL-XL, MCL-1, BAX and BID. Reprod. Domest. Anim., v.47, , p.10271036, 2012.

HARDARSON, T.; VAN LANDUYT, L.; JONES, G. The blastocyst. Hum. Reprod., v.27, p.72-91, 2012.

KARBOWSKI, M.; YOULE, R.J. Dynamics of mitochondrial morphology in healthy cells and during apoptosis. Cell Death Differ., v.10, p.870$880,2003$.

MORTENSEN, M.; FERGUSON, D.J.; EDELMANN, M. et al. Loss of autophagy in erythroid cells leads to defective removal of mitochondria and severe anemia in vivo. Proc. Natl. Acad. Sci., v.107, p.832-837, 2010.

PARRISH, J.J.; PARRISH, J.L.; FIRST, N.L. Effect of swim-up separation and heparin pretreatment of frozen-thawed spermatozoa on in vitro fertilization of bovine oocytes. Biol. Reprod., v.30, Suppl.1, p.112, 1984.

PASCUAL, M.E.; SLOWING, K.; CARRETERO, E. et al. Lippia: traditional uses, chemistry and pharmacology: a review. $J$. Ethnopharmacol., v.76, p.201-214, 2001.

PEREIRA, D.C.; DODE, M.A.N.; RUMPF, R. Evaluation of different culture systems on the in vitro production of bovine embryos. Theriogenology, v.63, p.1131-1141, 2005.
PEREIRA, E.C.M. Produção de oócitos $e$ embriões bubalinos: efeitos da época do ano e da adição de óleo essencial de Lippia origanoides na maturação in vitro. 2015. 128f. Tese (Doutorado em Biotecnologia Animal) - Faculdade de Medicina Veterinária e Zootecnia, Universidade Estadual Paulista, Botucatu, SP.

PEREIRA, R.M.; MARQUES, C.C. Animal oocyte and ambryo cryopreservation. Cell Tissue Bank., v.9, p.267-277, 2008.

RIZOS, D.; CLEMENTE, M.; BERMEJOALVAREZ, P. et al. Consequences of in vitro culture conditions on embryo development and quality. Reprod. Domest. Anim., v.43, p.44-50, 2008.

ROCHA-FRIGONI, N.A.S.; LEÃO, B.C.S.; DALL'AQUA, L.C. et al. Improving the cytoplasmic maturation of bovine oocytes matured in vitro with intracellular and/or extracellular antioxidants is not associated with increased rates of embryo development, Theriogenology, v.86, p.1897-1905, 2016.

SALZANO, A.; ALBERTO, G.; ZULLO, G. et al . Effect of resveratrol supplementation during culture on the quality and cryotolerance of bovine in vitro produced embryos. Anim. Reprod. Sci., v.151, p.91-96, 2014.

SARRAZIN, S.L.F.; SILVA, L.A.; OLIVEIRA, R.B. et al. Antibacterial action against food-borne microorganisms and antioxidant activity of carvacrol-rich oil from Lippia origanoides Kunth. Lipids Health Dis., v.14, p.145, 2015.

SCHNEIDER, C.A.; RASBAND, W.S.; ELICEIRI, K.W. NIH Image to ImageJ: 25 years of image analysis. Nat. Methods, v.9, p.671-675, 2012.

SENEDA, M.M.; ESPER, C.R.; GARCIA, J.M. et al. Relationship between follicle size and ultrasound-guided transvaginal oocyte recovery. Anim. Reprod. Sci., v.67, p.37-43, 2001.

SHIN, H.; CHOI, S.; LIM, H.J. Relationship between reactive oxygen species and autophagy in dormant mouse blastocysts during delayed implantation. Clin. Exp. Reprod. Med., v.41, p.125-131, 2014. 
SOLLECITO, N.V.; PEREIRA, E.C.M.; GRAZIA, J.G.V. et al. Antioxidant activity of essential oil obtained from Lippia origanoides improves the quality of bovine embryos produced in vitro. Arq. Bras. Med. Vet. Zootec., v.71, p.723731, 2019.

SUN, W.J.; PANG, Y.W.; LIU, Y. et al. Exogenous glutathione supplementation in culture medium improves the bovine embryo development after in vitro fertilization. Theriogenology, v.84, p.716-723, 2015.

TEIXEIRA, M.L.; CARDOSO, M.G.; FIGUEIREDO, A.C.S. et al. Essential oils from Lippia origanoides Kunth. and Mentha spicata L: chemical composition, insecticidal and antioxidant activities. Am. J. Plant Sci., v.5, p.1181-1190, 2014.

TIMME-LARAGY, A.R.; GOLDSTONE, J.V.; IMHOFF, B.R. et al. Glutathione redox dynamics and expression of glutathione-related genes in developing embryo. Free Radic. Biol. Med., v.65, p.89-101, 2013.

UFER, C.; WANG, C.C.; BORCHERT, A. et al. Redox control in mammalian embryo development. Antioxid. Redox. Signal, v.13, p.833-875, 2010.

\begin{abstract}
VAN BLERKOM, J. Occurrence and development consequences of aberrant cellular organization in meiotically mature human oocytes after exogenous ovarian hyperestimulation. $J$. Eletron. Microsc. Tech., v.16, p.324-346, 1990.
\end{abstract}

WILDING, M.; COPPOLA, G.; DALE, B. et al. Mitochondria and human preimplantation embryo development. Reproduction, v.137, p.619, 2009.

ZULLO, G.; ALBERO, G.; NEGLIA, G. et al. Lergothioneine supplementation during culture improves quality of bovine in vitro-produced embryos. Theriogenology, v.85, p.688-697, 2016a.

ZULLO, G.; GANDITIIS, C.; PERO, M.E. et al. Crocetin improves the quality of in vitroproduced bovine embryos: Implications for blastocyst development, cryotolerance, and apoptosis. Theriogenology, v.86, p.1879-1885, 2016 b. 